\title{
The Degree of Availability of E-Learning Competencies : A Survey Study Among the Faculty Staff Members at Jazan University- Saudi Arabia Mahasin Gad Alla Mohamed*, Kadia Mohammad Alfaifi
}

Educational Technology Department, Jazan University, Jazan, Saudi Arabia

\begin{abstract}
The purpose of this study was to investigate the availability of e-learning competencies among the faculty staff members at Jazan University, Kingdom Saudi Arabia. The study conducted in the academic year 2020. A purposive sample of (330) male and female staff members of Jazan University, was chosen. The questionnaire was used for collecting data. SPSS used for analyzing data. Appropriate statistics for description (frequencies, percentage, means, standard deviations, Mann Whitney Test, T-Test and One-Way ANOVA Test) were used. The results showed that: There were significant differences in the aspects (competencies of e-learning culture) and (competencies of designing and managing e-learning) related to college variable, in favor of humanities colleges. There were significant differences between the faculty staff member responses on the availability of e-learning competencies, related to gender variable, in favor of male gender. There were significant differences in the aspect (competencies of designing and managing e-learning) related to experience variable, in favor of experience from 5 years and more. There were significant differences in the elearning competencies, due to the difference in qualification variable. There were significant differences in the e-learning competencies, related to the training courses.

Keywords : E-Learning, E-Learning Competencies, Faculty Staff Members, Communication Technologies, Survey Study
\end{abstract}

Article Info

Volume 8, Issue 2

Page Number : 489-509

Publication Issue

March-April-2021

\section{Article History}

Accepted : 15 April 2021

Published : 20 April 2021

\section{INTRODUCTION}

\section{Background}

The scientific and technological progress that the world is witnessing today, necessitates many and varied duties on peoples and individuals, and drives them to initiate using the maximum available from this contemporary technology to develop teaching and learning methods, in order to get rid of traditional methods, to keep pace with the rapidly changing world, therefore, it is necessary to prepare individuals with special characteristics who are able to adapt to the scientific and technological changes that will happen in the future (Kulab, 2011, p2).

The growing demand for higher education, and awareness of higher educational institutions and 
stakeholders, and the widespread penetration of communications and information technology affecting the current era (Al-Saif, 2009, p 2). These developments have made a great force and influence of computers on the educational process, as it provided new tools and interactive means to overcome time and distance to reach students anywhere and at any time (Al-Hady, 2005, p142).

The educational process is one of the processes that go through many stages of continuous development and growth due to its innovations in many and varied aspects, the educational process is no longer based only on the teacher and the student and the curriculum, but many innovations emerged from the beginning of the use of computers in education. These recent technological developments are accelerating in various areas of life, as technology has become coexist with us in our daily lives, whether at home or work, and the student needs to develop their technological skills and their understanding of the world in which they live, where technological education helps the student to develop the adaptive feature required for work in a rapidly changing world (hassan, 2017, p 1).

As a result of the continuous changes in the areas of education and training, the term e-learning has emerged a great deal in education and training services, and this term has spread very quickly (Kulab, 2011, p2) and widely throughout the world, due to its benefits. It helps teachers and students to develop information and communication technologies in the teaching and learning processes, as the ease of using the internet has led to many other technical means to displace the classrooms with the electronic space (Sultan, 2001, p165).

E-learning has become an effective pattern in education that combines digital transmission of content and the availability of educational support and services, and what is meant by providing support is the role of the teacher in supporting and assisting the student at any time, and this is what distinguishes e-learning from computer education as a simple educational presentation tool (Kinsara, 2005, p20).
E- learning is defines as: " A creative way to present a well-designed, pre-designed, interactive environment accessible to anyone, anywhere and anytime, using the features and resources of the Internet and digital technologies in conformity with educational design principles appropriate for an open, flexible and distributed learning environment" (Sallam, 2013, p9).

Technology has changed the possibilities within teaching and learning. Traditional classrooms, no longer have to be designed in that manner. Faculty members should use modern technologies to improve the teaching and learning environment. Therefore, they have to possess technological competencies in using hardware and software inside classrooms (Duffin, 2020, p 30).

Competencies are defined as: " The various forms of performance that represent the minimum required to achieve a goal, they are the sum of the attitudes, forms of understanding and skills that would facilitate the educational process to achieve its mental, emotional and psychological goals" (Al-Umary, 2009, p14).

The use of information and communications technology in the field of education is a strategic choice and an urgent necessity in light of the great knowledge flow, the technological and the communications revolution, requires preparing teachers and students to deal with these technologies and the need for teachers to possess these modern technological competencies (Merdas, 2014, p. 41).

The competent e-learning teachers are the key to successful e-Learning implementations, so, they should have the appropriate skills and experience for the effective implementation of e-learning in their classrooms. Online teachers should possess e-learning competencies and skills than a traditional teacher does. These competencies and skills are systematically constructing the competencies of the teachers who want to teach online (Gulbahar \& Kalelioglu, 2015, pp. 140-143). 


\section{Previous studies}

Hassan (2017) study was aimed to explore elearning competencies among secondary school teachers in Omdurman city, Sudan. The researcher used the descriptive analytical method because it most suits the study. The sample of the study consisted of (139) secondary school teachers who were randomly selected; the researcher used questionnaire for data collection and SPSS for data analysis. The study has arrived at the following results: The competencies that relate to the e-learning culture of the secondary school teachers were available at an intermediate degree. The competencies that relate to the use of the computer were available to the secondary school teachers to a high degree. The competencies that relate to the use of the Internet are available to secondary school teachers with an intermediate degree. The competencies that relate to software and multimedia design are available to secondary school teachers with an intermediate degree. The competencies that go into the use of modern technologies are available to secondary school teachers with an average degree.

Sayegh (2017) study was aimed to identifying the degree to which e-learning competencies are practiced among faculty members, King Abdelaziz University (KAU), College of Education, Kingdom Saudi Arabia (KSA). The sample size was (135). A questionnaire was used for collecting data. The study results were as follows: the degree to which faculty members at KAU possessed e-learning competencies was available at medium degree. E-learning practiced by the faculty members at KAU was available at medium degree. There were statistically significant differences in the degree of the faculty members' possession of e-learning competencies due to the college variable, in favor of the college of computing and information technology; However, there were no statistically significant differences in the degree of the faculty members' possession and the extent to which e-learning competencies were practiced; There were statistically significant differences in the degree of the faculty members' possession and practicing of elearning competencies due to country of obtaining qualification variable, in favor of individuals who graduated from Universities in Western countries.

Merdas (2014) study was conducted to verify elearning competencies among teachers of Islamic education teachers at higher school in some States of Kuwait. Purposive sample size was (135) teachers. A questionnaire was used for collecting data. Data was analyzed by SPSS program. The study came out with the following results: There was severe impairment in the teachers' ability to plan and design of any educational software, or use electronic tests to assess students in e-learning. In the light of the results, the researchers recommended that: Holding more training courses for Islamic education teachers at higher school to develop and enhance their competencies in planning and designing e-learning techniques. Establishing an integrated training program by the Ministry of Education for Islamic education teachers at higher school in Kuwait to train on developing their competencies in planning and designing e-learning techniques.

Ahmed (2014) study was aimed to identifying the level of E-learning and its competencies availability for the faculty staff members at the colleges of Sudanese Universities in Khartoum state, Sudan, and to which extent the faculty staff members use it. The study was carried out during the period 2013-2014. Descriptive method was used. the study sample consisted of (188) faculty staff members. A questionnaire and interviews were used for collecting data. The study came out with the following results: The competencies of using the computer and the Internet among the faculty members of the Colleges of Education in the Sudanese universities in Khartoum State were available in a high degree. The e-learning competencies of the faculty members at the colleges of education in the Sudanese universities in Khartoum state were generally available at a medium level; The competencies of planning and evaluation are widely available among the faculty 
members of the Colleges of Education in Sudanese universities in Khartoum State. Through these results, the study reached a set of recommendations, the most important of which are: the need to train faculty members in colleges of education to use e-learning, the need to motivate faculty members to use elearning, provide adequate budget for the use of elearning in colleges of education in Sudanese universities, and establish an appropriate infrastructure.

Sallam (2013) study was aimed to identify the availability of e-learning competencies among faculty members at the University of Ibb, Yemen, the researcher used the descriptive survey method. A questionnaire used for collecting data. The study sample consisted of (77) faculty members. The results showed that faculty members at the University of Ibb Yemen possess the competencies of e-learning in the aspect of the use of computer and its Peripherals, the aspect of the use of networks and Internet was available with high degree, and possess the qualifications of a culture of e-learning, the design and management of e-learning was available with medium degree.

Al-Anzi (2012) study conducted to find out the faculty members' viewpoint on e-learning in the Kingdom of Saudi Arabia. This study included 500 faculty members from Al-Jouf University and Northern Border University. A questionnaire was used for collecting data. The study came out with the following results: the faculty members have the ability to deal with computers more when compared to their abilities to deal with e-learning, all the faculty members, whether male or female, felt that they are more confident and more suitable for using e-learning and more comfortable with it. The study showed that the female was more enjoyable in elearning and more preferable to using multimedia. The study indicated that there were no significant differences between males and females in their perceptions of the benefit of e-learning. The study also included knowledge of the self-efficacy of e- learning, and it was found that members under the age of 45 years have above average competency of members over the age of 45 years. Whereas, members between the ages of 27-32 are more enjoyable in using e-learning than the older members. Younger members indicated that e-learning is beneficial. The study, also, showed that members at the age of 26 have more intentions to use e-learning than members at the age of 39-44 years. The study indicated that members younger than (45) scored highly for their satisfaction with the system.

Kulab (2011) study aimed to identifying the degree of e-learning competencies of the computerized interactive learning teachers at UNRWA schools in Gaza and its relationship to their attitudes. The sample size was (62) teachers of all teachers at UNRWA schools in Gaza, (26) male and (36) female teachers. A questionnaire was used for collecting data. Percentage, Pearson correlation, $(\mathrm{T})$ test and one-way ANOVA were used. The results showed that: There are significant differences at the level of significant (0.05) between the average male and female teachers' grades at the centre of the culture of e-learning, driving computer in favour of males, while there are differences between the averages of the male and female teachers at the centre of the leadership of the Internet, the focus of software design and multimedia multi-educational, There are no statistically significant differences at the significance level (0.05) in all aspects of e-learning competencies according to the number of years of service, There is a correlation at the significance level (0.05) between the degree of availability of e-learning competencies and the degree of trend towards computerized interactive learning. The higher the competencies, the greater the positive trend towards interactive learning. In light of the results, the researcher recommended the necessity of holding training courses for teachers to acquire basic competencies for designing lessons and activities electronically and disseminating the experience of interactive, interactive learning in the schools of the Relief Agency in Gaza. 
Al-Umary (2009) study examined the recognition of electronic learning competencies and their degree of availability among the high school teachers at AlMekhwah Educational Governorate. The study sample consisted of all high school teachers at AlMekhwah Educational Governorate, which reached (306) teachers. A questionnaire used for collecting data. SPSS was used for analysing data. The study results were as follows: There were statistically significant differences at the level of significant (0.05) between the study participants responses due to years of experience in favour of modern service teachers. There were no statistically significant differences at the level of significant (0.05) between the study participants responses due to computer and network training courses. According to the study results, the researchers recommended the following: conducting educational training courses in e-learning field; conducting special courses to provide the teachers with basic electronic skills for lessons and activities; linking the teachers functional performance with training courses attendance and their use of available systems in their classrooms.

Al- Saif (2009) study sought to reveal E-learning Competencies of female faculty staff at the College of Education, King Saud University. The study used descriptive methodology. A questionnaire was used for collecting data. The study sample reached (245) members where (153) have responded. After collecting the related and analysing the related data were analyses by SPSS program. A number of results have been obtained, the most important ones are: The e-learning competencies of the female faculty staff are medium in general, they are represented in high level of using PC in the first place. Also, this is followed by using internet on a high level as well as e-courses design and teaching management system use on a medium level. The study found out that there are statistically significant differences of indication among faculty staff attributed to age regarding the mean of using PC competencies, in favour of staff who are less than 35 years old. There are no statistically significant differences of indication attributed to age variable in the mean of the other competencies. There are statistically significant differences of indication attributed to variables of scientific degree, place of acquisition, experience in university teaching or the related training courses. The study found out that the obstacles impeding female faculty staff and other related staff from their competencies' development represent in many administrations and teaching loads, discrepancy of academic subjects' time table with training programs provided inside and outside the university; this is in addition to difficulty of designing the e-courses. The study found out that the suitable recommendations of e-learning competencies, development of female faculty staff and other related staff represent in decreasing the teaching load, building training programs conforming to their requirements, variety of provided training programs methods including standard lessons, single learning method and distance learning method. The study provided a recommended method to develop e-learning competencies including mechanisms and policies of development; this is in addition to development programs conforming to three stages: (pre-preparation stage, preparation stage and post training stage) in addition to a number of research suggestions resulted from this study outcomes.

Through the previous studies mentioned above, the researchers found that: four of these studies were conducted at Saudi Arabia, three of which are similar the current study in the topic and study population, such as Sayegh (2017), Al-Saif (2009), Al-Anazi (2012) but differs in study spatial boundaries (KAU, KSU, AlJouf U.); the fourth study (Al-Umary, 2009) was similar to the current study in the topic, but differs in the study population and special boundaries (higher school teachers at Al-Makhwah Educational governate. The current study applied in southern KSA (Jazan University) - Jazan City- and the study sample were (faculty staff members (Male \& Female)). 


\section{METHODS AND MATERIAL}

\section{Research Goal}

The purpose of this study was to investigate the availability of e-learning competencies among the faculty staff members at Jazan University, Kingdom Saudi Arabia.

\section{Sample and Data Collection}

The sample had been selected from the study population by using a purposive sample. A questionnaire was used for collecting data. The researchers had used a readymade questionnaire designed by (Sallam, 2013). The questionnaire consisted of four aspects, first aspect "the competencies of using the computer and its accessories" which consisted of (16) items; the second aspect " the competencies of using networks and the Internet", which consisted (14) items; the third aspect " the competencies of E-learning culture", which consisted of (16) items; the fourth aspect " the competencies of designing and managing E-learning", which consisted of (16) items. Sallam (2013), measured the validity and reliability of the questionnaire by using: Pearson Correlation Coefficient and Cronbach Alpha Coefficient. A typical fifth-level Likert item had been used in the questionnaire, the fifth-level Likert item as follows: (Strongly Applicable), (Applicable), (Applicable to some extent), (Not applicable), (Not Strongly Applicable). The data were analyzed with SPSS personal computer program.

\section{The Study Hypotheses}

There is a degree of availability of E-learning competence among the faculty staff members at Jazan University.

There are no significant differences at the level of significance (0.05) between faculty staff members' responses on the availability of E-learning competencies, related to college variable:
H0: $\mu 1=\mu 2$

HA: $\mu 1 \neq \mu 2$

There are no significant differences at the level of significance $(0.05)$ between faculty staff members' responses on the availability of E-learning competencies, related to experience variable.

H0: $\mu 1=\mu 2$

HA: $\mu 1 \neq \mu 2$

There are no significant differences at the level of significance $(0.05)$ between faculty staff members' responses on the availability of E-learning competencies, related to qualification variable.

H0: $\mu 1=\mu 2$

HA: $\mu 1 \neq \mu 2$

There are no significant differences at the level of significance $(0.05)$ between faculty staff members' responses on the availability of E-learning competencies, related to training course variable.

H0: $\mu 1=\mu 2=\mu 3$

HA: $\mu 1 \neq \mu 2 \neq \mu 3$

(or at least two means are not equal)

\section{Analysing of Data}

All data were analyzed with the SPSS personal computer program. Appropriate statistics for description (frequencies, percentage, means, standard deviations, Mann Whitney test, T-Test, and ANOVA One Way Test) were used.

\section{RESULTS AND DISCUSSION}

\section{RESUTLTS}

\section{A. Research Participants}

The research participants consisted of (330) staff members, who participated in this study and filled out and submitted the electronic questionnaire. All participants were staff members, in different colleges at Jazan university. Information pertaining to the personal and vocational details of the study participants is given in Table (1). 
TABLE 1

THE PERSONAL DATA OF STUDY PARTICIPANTS

\begin{tabular}{|c|c|c|c|}
\hline Variable & & $\begin{array}{l}\text { Frequenc } \\
\mathrm{y}(\mathrm{F})\end{array}$ & $\begin{array}{l}\text { Percentag } \\
\text { e (\%) }\end{array}$ \\
\hline \multirow{2}{*}{ Gender } & Male & 120 & $36.4 \%$ \\
\hline & Female & 210 & $63.6 \%$ \\
\hline \multirow{6}{*}{$\begin{array}{l}\text { Qualificatio } \\
\mathbf{n}\end{array}$} & Professor & 12 & $3.6 \%$ \\
\hline & $\begin{array}{l}\text { Associate } \\
\text { Professor }\end{array}$ & 39 & $11.8 \%$ \\
\hline & $\begin{array}{l}\text { Assistant } \\
\text { Professor }\end{array}$ & 141 & $42.7 \%$ \\
\hline & Lecturer & 123 & $37.3 \%$ \\
\hline & $\begin{array}{l}\text { Teaching } \\
\text { Assistant }\end{array}$ & 12 & $3.6 \%$ \\
\hline & $\begin{array}{l}\text { Language } \\
\text { Teacher }\end{array}$ & 3 & $1.0 \%$ \\
\hline \multirow[t]{2}{*}{ College } & $\begin{array}{l}\text { Humanitie } \\
\text { s }\end{array}$ & 138 & $41.8 \%$ \\
\hline & Science & 192 & $58.2 \%$ \\
\hline \multirow{3}{*}{ Experience } & $\begin{array}{l}\text { Less than } 5 \\
\text { years }\end{array}$ & 15 & $4.6 \%$ \\
\hline & $5-10$ years & 174 & $52.7 \%$ \\
\hline & $\begin{array}{l}\text { More than } \\
10 \text { years }\end{array}$ & 141 & $42.7 \%$ \\
\hline \multirow{3}{*}{$\begin{array}{l}\text { Training } \\
\text { courses }\end{array}$} & $\begin{array}{l}\text { Non } \\
\text { training } \\
\text { course }\end{array}$ & 42 & $12.7 \%$ \\
\hline & $1-2$ courses & 132 & $40.0 \%$ \\
\hline & $\begin{array}{l}\text { More than } \\
\text { three } \\
\text { courses }\end{array}$ & 156 & $47.3 \%$ \\
\hline
\end{tabular}

(63.6\%) (f: 210) of the study participants were female, with (36.4\%) (f: 120) male. In review of participants qualification, Assistant professor is the largest group (42.7\%) (f: 141), lecturer is the second largest (37.3\%) (f: 123), Associate professor is third largest (11.8\%) (f: 39), Professor and teaching assistant are the fourth largest (3.6\%) (f: 12), and language teacher is the fifth largest (1\%) (f: 3). In the review of College correlation, Science is the largest group (58.2\%) (f: 192), Humanities is the second largest (41.8\%) (f: 138). In the term of Experience correlation, from 5 to 10 years is the largest group (52.7\%) (f: 174), More than 10 years is the second largest group (42.7\%) (f: 141), less than 5 years is the third largest group (4.6\%) (f: 15). In the review of Training Courses in E-learning, more than three courses, is the largest group (47.3\%) (f: 156), from one to two courses is the second largest group (40.0\%) (f: 132), and Non training course is the third largest group (12.7\%) (f: 42).

\section{B. The first hypothesis}

There is a degree of availability of E-learning competence among the faculty staff members at Jazan University.

To verify this hypothesis, the questionnaire was divided into four aspects, each aspect consisted of a number of items. Mean, standard deviation values for every item were calculated.

\section{First Aspect: The competencies of using computer and} its accessories

This aspect consisted (16) items (1 to 16). Mean, standard deviation values for every item of the first aspect (The competencies of using computer and its accessories) were calculated. Table (2) displayed the mean and standard deviation values. 
TABLE 2

MEAN AND STD. DEVIATION ANALYSIS FOR

COMPUTER AND ITS ACCESSORIES COMPETENCIES

\begin{tabular}{cccc}
\hline $\mathbf{N}$ & Competence & Mea & Std. \\
o. & & $\mathbf{n}$ & Deviation
\end{tabular}

1. I have the ability to

handle Windows

$4.72 \quad 0.44$

I have the ability to

operate computer

2. peripherals such as:

$4.69 \quad 0.56$

microphone, camera,

printer, scanner)

I can use external

storage such as: CDs,

3. optical pen, external $\quad 4.61 \quad 0.67$

hard disk, flash

memory

I can install different

programs on Windows

$4.35 \quad 0.89$

I can remove different

5. computer programs

from Windows

$\begin{array}{ll}4.35 & 0.89\end{array}$

operating system

I have the ability to

6. create and organize

folders

I can distinguish

between file types by

7. extension, such as:

$4.50 \quad 0.65$

Docx., Pptx., Html, pdf,

AVI

I can distinguish

between image types

8. according to the

extension, such as:

$4.07 \quad 0.98$

JPEG or JPG, PNG,

RAW, BMP, TIFF, GIF

$\begin{array}{llcc}\text { N } & \text { Competence } & \text { Mea } & \text { Std. } \\ \text { o. } & & \text { n } & \text { Deviation }\end{array}$

I have the ability to use

9. antivirus and $\quad 4.18 \quad 0.91$

protection software

I can compress or

decompress files using a

10. program to decompress $4.30 \quad 0.93$

and compress files such

as: WinZip, WinRAR

I can use Microsoft

Word perfectly

11. (writing, editing,

$4.77 \quad 0.44$

formatting, tables,

revising)

12. I can convert text

documents into Pdf

$4.81 \quad 0.40$

I use PowerPoint

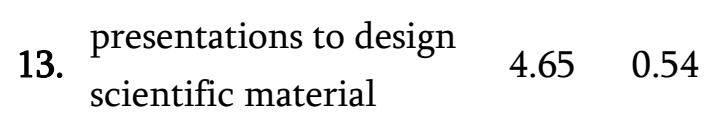

presentations

I can convert audio and

video files from one

14. format to another using $3.82 \quad 1.05$

the appropriate

programs

I can check the defect

if the software or

15. hardware attached to $\quad 3.76 \quad 1.08$

the computer is not

working

I can use the Data

16. Show and connect it to $4.28 \quad 1.00$

a computer

Total

$4.41 \quad 0.74$

Table (2) showed values of mean and std. deviation for computer and its accessories competencies. The 
biggest mean value (4.81) with standard deviation (0.40) is for the participants who can convert text documents into pdf. The second biggest mean value (4.77) with standard deviation (0.44) is for those who can use Microsoft Word perfectly (writing, editing, formatting, tables, revising). The third biggest mean value (4.72) with standard deviation (0.44), is for the participants who have the ability to handle Windows. The fourth biggest mean (4.71) with standard deviation (0.52) is for the participants who have the ability to create and organize folders. The fifth biggest mean (4.69) with standard deviation (0.56) is for the participants who have the ability to operate computer peripherals such as: microphone, camera, printer, scanner). The sixth biggest mean (4.65) with standard deviation (0.54) is for the participants who use PowerPoint presentations to design scientific material presentations. The seventh biggest mean (4.61) with standard deviation (0.67) is for the participants who can use external storage such as: CDs, optical pen, external hard disk, flash memory. The eighth biggest mean (4.50) with standard deviation (0.65) is for the participants who can distinguish between file types by extension, such as: Docx., Pptx., Html, pdf, AVI. The ninth biggest mean (4.35) with standard deviation (0.89) is for the participants who can remove different computer programs from Windows operating system and who can install different programs on Windows. The tenth biggest mean (4.30) with standard deviation (0.93) is for the participants who can compress or decompress files using a program to decompress and compress files such as: WinZip, WinRAR. The eleventh biggest mean (4.28) with standard deviation (1.00) is for the participants who can use the Data Show and connect it to a computer. The twelfth biggest mean (4.18) and standard deviation (0.91) is for the participants who have the ability to use antivirus and protection software. The Thirteenth biggest mean (4.07) and standard deviation (0.98) is for the participants who can distinguish between image types according to the extension, such as: JPEG or JPG, PNG, RAW, BMP,
TIFF, GIF. The fourteenth biggest mean (3.82) and standard deviation (1.05) is for the participants who can convert audio and video files from one format to another using the appropriate programs. The fifteenth biggest mean (3.76) and standard deviation (1.08) is for the participants who can check the defect if the software or hardware attached to the computer is not working.

This result due to the nature of the faculty members at Jazan University, since the majority of them have a doctorate during recent years, and they have used computers during their studies, in addition to the availability of computers with most of the faculty staff members, especially after Jazan University dispensed laptop devices for all staff members in the university. Also, these competencies do not require high skills to master them, and they cannot be dispensed with while we live in the twenty-first century.

\section{Second Aspect: The competencies of using networks and the Internet}

This aspect consisted (14) items (17 to 30). Mean, standard deviation values for every item of the second aspect (The competencies of using networks and the Internet) were calculated. Table (3) displayed the mean and standard deviation value.

TABLE 3:

MEAN AND STD. DEVIATION ANALYSIS FOR NETWORK AND INTERNET COMPETENCIES

No. Competence Mean $\begin{gathered}\text { Std. } \\ \text { Deviation }\end{gathered}$

I can deal efficiently with web browsers like: Firefox,

17. Internet Explorer, Google

Chrome

I can use search engines

18. like: Google, Yahoo to ge 4.75 0.54

scientific information 
\begin{tabular}{lc} 
No. $\quad$ Competence \\
\hline 19. I can diagnose and address
\end{tabular}

19. simple network problems

$3.98 \quad 1.09$

I have e-mail handling

20. skills (send-receive)

I can handle Attachment

21. files of all kinds - text, $4.70 \quad 0.62$

images, audio, video

I use social networking sites

22. such as; Facebook, Twitter

$4.45 \quad 0.81$

I have the ability to

23. download files from the

Internet or upload them.

24. I can use the mailing lists

I use some instant chat

25. programs such as;

Messenger, Skype, Yahoo

I can use online video and

26. audio conferencing

I can play online videos

27. like: YouTube

I participate in forums and

28. sites related to my specialty

I can search specialized databases and electronic

29. information such as 4.00 1.07 databases: ERIC, Science

Director

30. my own website (site)

Total 4.41

Table (3) showed values of mean and std. deviation for network and INTERNT competencies. The biggest mean value (4.80) with standard deviation $(0.48)$ is for

the participants who have e-mail handling skills (send-receive). The second biggest mean value (4.75) with standard deviation (0.54) is for those who can use search engines like: Google, Yahoo to get scientific information. The third biggest mean value (4.74) with standard deviation (0.47), is for the participants who can deal efficiently with web browsers like: Firefox, Internet Explorer, Google Chrome. The fourth biggest mean (4.71) with standard deviation (0.47) is for the participants who have the ability to download files from the Internet or upload them. The fifth biggest mean (4.70) with standard deviation (0.62) is for the participants who can handle Attachment files of all kinds - text, images, audio, video. The sixth biggest mean (4.65) with standard deviation (0.57) is for the participants who can play online videos like: YouTube. The seventh biggest mean (4.53) with standard deviation (0.62) is for the participants can use the mailing lists. The eighth biggest mean (4.50) with standard deviation $(0.78)$ is for the participants who use some instant chat programs such as; Messenger, Skype, Yahoo. The ninth biggest mean (4.45) with standard deviation $(0.81)$ is for the participants who use social networking sites such as; Facebook, Twitter. The tenth biggest mean (4.27) with standard deviation (0.89) is for the participants who can use online video and audio conferencing. The eleventh biggest mean (4.10) with standard deviation (1.02) is for the participants who participate in forums and sites related to my specialty. The twelfth biggest mean (4.00) with standard deviation (1.07) is for the participants can search specialized databases and electronic information such as databases: ERIC, Science Director. The thirteenth biggest mean (3.98) with standard deviation (1.09) is for the participants who can diagnose and address simple network problems. The fourteenth biggest mean (3.60) with standard deviation (1.14) is for the participants who have the ability to create my own website (site).

This result due to the nature of the faculty members at Jazan University, since the majority of them have a 
doctorate during recent years, and they have used computers during their studies, in addition to the members, especially after Jazan University dispensed laptop devices for all staff members in the university. Also, these competencies do not require high skills to master them, and they cannot be dispensed with while we live in the twenty-first century.

The researchers attribute the results of the study in the competencies of using networks and Internet to the widespread use of computers and the Internet in recently, and its availability among many people in general and faculty staff members in particular, where they have a high level of culture and education that enables them to access the Internet and interact with others, in addition to the availability of the Internet to most of the faculty staff members at homes, or at Jazan University.

\section{Third Aspect: The competencies of E-learning culture}

This aspect consisted (16) items (31 to 46). Mean, standard deviation values for every item of the first aspect (The competencies of E-learning culture) were calculated. Table (4) displayed mean and standard deviation results:

TABLE 4

MEAN AND STD. DEVIATION ANALYSIS FOR THE COMPETENCIES OF E-KNOWLEDGE CULTURE

No. Competence Mean $\begin{gathered}\text { Std. } \\ \text { Deviation }\end{gathered}$

I have an

31. understanding of the $\begin{array}{ll}4.54 & 0.59\end{array}$ concept of e-learning

0.64

32. I have knowledge of e-learning goals

33. I have knowledge of $\quad 4.51 \quad 0.68$

33. I have knowledge of $\quad 4.51 \quad 0.68$ availability of computers with most of the faculty staff

No. Competence Mean Std. Deviation

learning

I have a good

34. knowledge of the

types of e-learning

35.

I know the downsides

of e-learning

I can distinguish

36.

between e-learning

and traditional

learning

I have knowledge of

37.

the difficulties facing

the e-learning

application

I have knowledge of

38

international e-

learning standards

such as: SCORM

I have knowledge of

e-learning

39. management systems

such as: Blackboard,

Moodle

I have knowledge of some e-content

40. authoring programs such as: Course Lab,

Author ware

I have a knowledge of

41. the concept of

Learning Objects

I have knowledge of the benefits of $\mathrm{e}^{-}$

42. the second-generation 


No. Competence Mean $\begin{gathered}\text { Std. } \\ \text { Deviation }\end{gathered}$

I have knowledge of

43. the steps to switching $4.11 \quad 0.86$ to e-learning

I have knowledge of

44. the teacher's roles in

0.69 e-learning

I have knowledge of

45. the student's roles in the e-learning

application

I have knowledge of

46. e-learning applied

models for teaching

Total

4.17

0.80

Table (4) showed values of mean and std. deviation for competencies of E-knowledge culture. The biggest mean value (4.71) with standard deviation $(0.45)$ is for the participants who can distinguish between elearning and traditional learning. The second biggest mean value (4.54) with standard deviation (0.59) is for those who have an understanding of the concept of elearning. The third biggest mean value (4.53) with standard deviation (0.64), is for the participants who have knowledge of e-learning goals. The fourth biggest mean (4.51) with standard deviation (0.68) is for the participants who have knowledge of the benefits of e-learning. The fifth biggest mean (4.46) with standard deviation (0.71) is for the participants who know the downsides of e-learning. The sixth biggest mean (4.44) with standard deviation (0.72) is for the participants who have knowledge of the difficulties facing the e-learning application and those who have knowledge of the student's roles in the elearning application. The seventh biggest mean (4.42) with standard deviation (0.69) is for the participants have knowledge of the teacher's roles in e-learning. The eighth biggest mean (4.34) with standard deviation (0.72) is for the participants who have knowledge of e-learning management systems such as: Blackboard, Moodle. The ninth biggest mean (4.26) with standard deviation $(0.81)$ is for the participants who have knowledge of e-learning applied models for teaching. The tenth biggest mean (4.23) with standard deviation (0.78) is for the participants who can have a good knowledge of the types of e-learning. The eleventh biggest mean (4.11) with standard deviation (0.86) is for the participants who have knowledge of the steps to switching to e-learning. The twelfth biggest mean (3.67) with standard deviation (1.03) is for the participants who have a knowledge of the concept of Learning Objects. The thirteenth biggest mean (3.52) with standard deviation (1.09) is for the participants who have knowledge of the secondgeneration concept of e-learning. The fourteenth biggest mean (3.29) with standard deviation (1.23) is for the participants who have knowledge of international e-learning standards such as: SCORM. The fifteenth biggest mean (3.18) with standard deviation (1.16) is for the participants who have knowledge of some e-content authoring programs such as: Course Lab, Author ware.

The researcher explains the result of the study in the e-learning competencies, to the government's interest in general and Jazan University in particular, and to the existence of a valid environment as this is also due to the application of this type of education recently in the shadow of the COVID 19.

\section{Fourth Aspect: The competencies of designing and managing E- learning}

This aspect consisted (16) items (47 to 62). Mean, standard deviation values for every item of the first aspect (The competencies of designing and managing E- learning) were calculated. Table (5) displayed mean and standard deviation results: 
TABLE 5

MEAN AND ETD. DEVIATION ANALYSIS FOR

THE COMPETENCIES OF DESIGNING AND

MANAGING E-LEARNING

No. Competence Mean $\begin{gathered}\text { Std. } \\ \text { Deviation }\end{gathered}$

47.

I can determine the

suitability of the course

to be taught

$4.35 \quad 0.75$

electronically

I have the ability to set

48. general goals for the e-

course

I can analyze the

49.

characteristics of

learners associated with

e-learning

I can formulate e-course

50.

learning goals in a clear,

measurable procedural

manner

I have the ability to

51. define steps for

0.89

designing online lessons

I have the ability to

52.

define electronic

content and

$4.17 \quad 0.85$

specifications

I can apply one of the

53. educational design

templates in e-learning

I have the ability to

convert design

specifications into

54. electronic content using

3.74

1.03

authoring tools like:

Course Lab, Author

ware, PowerPoint

\begin{tabular}{cc} 
No. & Competence \\
\hline I can include online \\
lessons with activitie
\end{tabular}

55. lessons with activities

that encourage student

$4.20 \quad 0.83$

interaction

I can include scenes and

56. enrichment links in e- $\quad 4.13 \quad 0.84$

lessons

I can choose appropriate

57. teaching and learning

$\begin{array}{ll}4.26 & 0.77\end{array}$

strategies for e-learning

I have the ability to

58. manage electronic

$\begin{array}{ll}4.11 & 0.89\end{array}$

dialogues

I can define the

59. feedback patterns that $\quad 4.11 \quad 0.89$
make e-learning

successful

I have the ability to use

assessment methods

60.

appropriate for e-

$4.15 \quad 0.84$

learning

I have the ability to

61. prepare students to take

responsibility for $\mathrm{e}^{-}$

$4.22 \quad 0.80$

learning

I can use an e-learning

62. system like: Blackboard, $4.51 \quad 0.64$

Moodle

Total

4.20

0.85

Table (5) showed values of mean and std. deviation for the competencies of designing and managing $\mathrm{E}$ learning. The biggest mean value (4.51) with standard deviation (0.64) is for the participants who can use an e-learning system like: Blackboard, Moodle. The second biggest mean value (4.35) with standard 
deviation (0.75) is for those who can determine the suitability of the course to be taught electronically. The third biggest mean value (4.30) with standard deviation (0.76), is for the participants who have the ability to set general goals for the e-course. The fourth biggest mean (4.26) with standard deviation (0.77) is for the participants who can choose appropriate teaching and learning strategies for elearning. The fifth biggest mean (4.22) with standard deviation $(0.80)$ is for the participants who have the ability to prepare students to take responsibility for elearning. The sixth biggest mean (4.13) with standard deviation (0.84) is for the participants who can include online lessons with activities that encourage student interaction. The seventeenth biggest mean (4.17) with standard deviation (0.85) is for the participants who have the ability to define electronic content and specifications. The eighteenth biggest mean (4.15) with standard deviation (0.84) is for the participants who have the ability to use assessment methods appropriate for e-learning. The nineteenth biggest mean (4.13) with standard deviation (0.84) is for the participants who have the ability to manage electronic dialogues. The twentieth biggest mean (4.11) with standard deviation (0.89) is for the participants who can define the feedback patterns that make e-learning successful, and for the participants who have the ability to define steps for designing online lessons and those who can include scenes and enrichment links in e-lessons. The twentyone biggest mean (4.06) with standard deviation (0.98) is for the participants who can analyse the characteristics of learners associated with e-learning. The twenty-two biggest mean (4.04) with standard deviation (1.02) is for the participants who can formulate e-course learning goals in a clear, measurable procedural manner. The twenty-three biggest mean (3.92) with standard deviation (0.99) is for the participants who can apply one of the educational design templates in e-learning. The twenty-four biggest mean (3.74) with standard deviation (1.03) is for the participants who have the ability to convert design specifications into electronic content using authoring tools like: Course Lab, Author ware, PowerPoint.

The researcher interprets the result of the study in the competencies of e-learning design and management aspect, that the sample of the faculty staff members at Jazan University have attended many training courses provided by the deanship of elearning at the university about designing and managing e-learning.

\section{The Second Hypothesis}

There are no significant differences at the level of significance (0.05) between faculty staff members' responses on the availability of E-learning competencies, related to college variable:

\section{HO: $\mu 1=\mu 2$ \\ $H A: \mu 1 \neq \mu 2$}

This hypothesis aimed to indicate that, whether the college variable has an effect on faculty staff members' responses on the availability of E-learning competencies. To test this hypothesis, the T-test was used for the difference between two independent sample averages and the results were shown in table (6).

\section{TABLE 6}

T-TEST TO DISPLAY DIFFERENCE BETWEEN THE STUDY PARTICIPANTS' RESPONDES ACCORDING TO COLLEGE VARIABLE

\begin{tabular}{|c|c|c|c|c|c|c|c|c|c|c|}
\hline \multirow{2}{*}{ Aspects } & \multirow{2}{*}{$\begin{array}{l}\text { Colle } \\
\text { ge }\end{array}$} & \multirow{2}{*}{$\mathbf{N}$} & \multirow{2}{*}{ Mean } & \multirow{2}{*}{$\begin{array}{l}\text { Std } \\
\text { Dev } \\
\text { iati } \\
\text { on }\end{array}$} & \multirow{2}{*}{$\mathbf{t}$} & \multirow{2}{*}{ df } & \multirow{2}{*}{$\begin{array}{l}\text { Sig. } \\
(2 \\
\text { tail } \\
\text { ed })\end{array}$} & \multicolumn{2}{|c|}{$\begin{array}{l}95 \% \\
\text { confidence }\end{array}$} & \multirow{2}{*}{$\begin{array}{l}\text { Sig } \\
\text {. }\end{array}$} \\
\hline & & & & & & & & $\mathbf{L}$ & $\mathbf{U}$ & \\
\hline \multirow{2}{*}{$\begin{array}{l}\text { 1-The } \\
\text { compete } \\
\text { ncies of } \\
\text { using } \\
\text { compute } \\
\mathrm{r} \text { and its } \\
\text { accessor } \\
\text { ies }\end{array}$} & $\begin{array}{l}\text { Hum } \\
\text { anitie } \\
\mathrm{s}\end{array}$ & 138 & 72.43 & $\begin{array}{l}7.9 \\
7\end{array}$ & \multirow{2}{*}{$\begin{array}{l}3.3 \\
33\end{array}$} & \multirow{2}{*}{$\begin{array}{l}3 \\
2 \\
8\end{array}$} & \multirow{2}{*}{$\begin{array}{l}0.0 \\
01\end{array}$} & \multirow{2}{*}{$\begin{array}{l}- \\
0.1 \\
11\end{array}$} & \multirow{2}{*}{$\begin{array}{l}6 . \\
262\end{array}$} & \multirow{2}{*}{$\begin{array}{l}0.7 \\
13\end{array}$} \\
\hline & $\begin{array}{l}\text { Scien } \\
\text { ce }\end{array}$ & 192 & 69.35 & $\begin{array}{l}8.4 \\
7\end{array}$ & & & & & & \\
\hline \multirow{2}{*}{$\begin{array}{l}\text { 2- The } \\
\text { compete } \\
\text { ncies of } \\
\text { using } \\
\text { network } \\
\mathrm{s} \text { and } \\
\text { the } \\
\text { Internet }\end{array}$} & $\begin{array}{l}\text { Hum } \\
\text { anitie } \\
\text { s }\end{array}$ & 138 & 63.43 & $\begin{array}{l}6.9 \\
9\end{array}$ & \multirow[b]{2}{*}{$\begin{array}{l}3.5 \\
68\end{array}$} & \multirow[b]{2}{*}{$\begin{array}{l}3 \\
2 \\
8\end{array}$} & \multirow[b]{2}{*}{$\begin{array}{l}0.0 \\
00\end{array}$} & \multirow[b]{2}{*}{$\begin{array}{l}0.0 \\
88\end{array}$} & \multirow[b]{2}{*}{$\begin{array}{l}5.4 \\
37\end{array}$} & \multirow[b]{2}{*}{$\begin{array}{l}0.9 \\
29\end{array}$} \\
\hline & $\begin{array}{l}\text { Scien } \\
\text { ce }\end{array}$ & 192 & 60.67 & $\begin{array}{l}6.8 \\
9\end{array}$ & & & & & & \\
\hline $\begin{array}{l}\text { 3- The } \\
\text { compete } \\
\text { ncies of }\end{array}$ & $\begin{array}{l}\text { Hum } \\
\text { anitie } \\
\text { s }\end{array}$ & 138 & 70.08 & $\begin{array}{l}8.0 \\
4\end{array}$ & $\begin{array}{l}5.4 \\
21\end{array}$ & $\begin{array}{l}3 \\
2 \\
8\end{array}$ & $\begin{array}{l}0.0 \\
00\end{array}$ & $\begin{array}{l}2.0 \\
83\end{array}$ & $\begin{array}{l}9.4 \\
02\end{array}$ & $\begin{array}{l}0.0 \\
00^{*}\end{array}$ \\
\hline
\end{tabular}


Mahasin Gadalla Mohamed et al Int J Sci Res Sci \& Technol. March-April-2021, 8 (2) : 489-509

\begin{tabular}{|c|c|c|c|c|c|c|c|c|c|c|}
\hline $\begin{array}{l}\text { E- } \\
\text { learning } \\
\text { culture }\end{array}$ & $\begin{array}{l}\text { Scien } \\
\text { ce }\end{array}$ & 192 & 64.34 & $\begin{array}{l}10 . \\
40\end{array}$ & & & & & & \\
\hline $\begin{array}{l}\text { 4- The } \\
\text { compete } \\
\text { ncies of } \\
\text { designin }\end{array}$ & $\begin{array}{l}\text { Hum } \\
\text { anitie } \\
\mathrm{s}\end{array}$ & 138 & 70.71 & $\begin{array}{l}9.1 \\
4\end{array}$ & \multirow{2}{*}{$\begin{array}{l}5.9 \\
79\end{array}$} & \multirow{2}{*}{$\begin{array}{l}3 \\
2 \\
8\end{array}$} & \multirow{2}{*}{$\begin{array}{l}0.0 \\
00\end{array}$} & \multirow{2}{*}{$\begin{array}{l}3.0 \\
74\end{array}$} & \multirow{2}{*}{$\begin{array}{l}11 . \\
485\end{array}$} & \multirow{2}{*}{$\begin{array}{l}0.0 \\
00^{*}\end{array}$} \\
\hline $\begin{array}{l}\mathrm{g} \text { and } \\
\text { managin } \\
\mathrm{g} \quad \mathrm{E}- \\
\text { learning }\end{array}$ & $\begin{array}{l}\text { Scien } \\
\text { ce }\end{array}$ & 192 & 63.43 & $\begin{array}{l}12 . \\
01\end{array}$ & & & & & & \\
\hline
\end{tabular}

*Significant differences at the level of significance (0.05)

As appeared in table (6), there were significant differences in the aspects, competencies of E-learning culture and the competencies of designing and managing E- learning, in favour of faculty members at humanities colleges, these results due to that, most of colleges of humanities courses taught through elearning. And it is also noticed that there are no statistically significant differences at the level of significance (0.05) in the remaining aspects of the study, due to the difference in the college variable (Humanities, Science).

\section{The Third Hypothesis}

There are no significant differences at the level of significance (0.05) between faculty staff members' responses on the availability of E-learning competencies, related to gender variable.

\section{HO: $\mu 1=\mu 2$ \\ $H A: \mu 1 \neq \mu 2$}

This hypothesis aimed to indicate that, whether the gender variable has an effect on faculty staff members' responses on the availability of E-learning competencies. To test this hypothesis, Mann Whitney $\mathrm{U}$ test was used for the difference between two independent sample averages and the results were shown in table (7).
TABLE 7

\section{MANN WHITNEY TEST FOR THE DIFFERENCES}

IN THE MEANS OF THE STUDY SAMPL RESPONSES ACCORDING TO THE GENDER

VARIABLE

\begin{tabular}{|c|c|c|c|c|c|c|}
\hline Aspects & Gender & $\mathbf{N}$ & $\begin{array}{l}\text { Mea } \\
\text { n } \\
\text { Ran } \\
\text { k } \\
\end{array}$ & $\begin{array}{l}\text { Sum of } \\
\text { Ranks }\end{array}$ & $\begin{array}{l}\text { Mann } \\
\text { Whitney } \\
\text { U }\end{array}$ & Sig. \\
\hline \multirow{2}{*}{$\begin{array}{l}\text { 1-The } \\
\text { competen } \\
\text { cies of } \\
\text { using } \\
\text { computer } \\
\text { and its } \\
\text { accessorie } \\
s\end{array}$} & Male & 123 & $\begin{array}{l}222 . \\
46\end{array}$ & $\begin{array}{l}2736 \\
3.00\end{array}$ & \multirow[b]{2}{*}{$\begin{array}{l}5724.0 \\
0\end{array}$} & \multirow[b]{2}{*}{$\begin{array}{l}0.00 \\
0\end{array}$} \\
\hline & Female & 207 & $\begin{array}{l}131 . \\
65\end{array}$ & $\begin{array}{l}2725 \\
2.00\end{array}$ & & \\
\hline \multirow{2}{*}{$\begin{array}{l}2-\text { The } \\
\text { competen } \\
\text { cies of } \\
\text { using } \\
\text { networks } \\
\text { and the } \\
\text { Internet }\end{array}$} & Male & 123 & $\begin{array}{l}229 . \\
74 \\
\end{array}$ & $\begin{array}{l}2825 \\
8.50\end{array}$ & \multirow[b]{2}{*}{$\begin{array}{l}4828.5 \\
0\end{array}$} & \multirow[b]{2}{*}{$\begin{array}{l}0.00 \\
0\end{array}$} \\
\hline & Female & 207 & $\begin{array}{l}127 . \\
33\end{array}$ & $\begin{array}{l}2635 \\
6.50\end{array}$ & & \\
\hline \multirow{2}{*}{$\begin{array}{l}3-\quad \text { The } \\
\text { competen } \\
\text { cies of E- } \\
\text { learning } \\
\text { culture }\end{array}$} & Male & 123 & $\begin{array}{l}221 . \\
77\end{array}$ & $\begin{array}{l}2727 \\
7.50\end{array}$ & \multirow{2}{*}{$\begin{array}{l}5809.5 \\
0\end{array}$} & \multirow{2}{*}{$\begin{array}{l}0.00 \\
0\end{array}$} \\
\hline & Female & 207 & $\begin{array}{l}132 . \\
07\end{array}$ & $\begin{array}{l}2733 \\
7.50\end{array}$ & & \\
\hline \multirow{2}{*}{$\begin{array}{l}\text { 4- The } \\
\text { competen } \\
\text { cies of } \\
\text { designing } \\
\text { and } \\
\text { managing } \\
\text { E- } \\
\text { learning }\end{array}$} & Male & 123 & $\begin{array}{l}215 . \\
99\end{array}$ & $\begin{array}{l}2656 \\
6.50\end{array}$ & \multirow[b]{2}{*}{$\begin{array}{l}6520.5 \\
0\end{array}$} & \multirow[b]{2}{*}{$\begin{array}{l}0.00 \\
0\end{array}$} \\
\hline & Female & 207 & $\begin{array}{l}135 . \\
50\end{array}$ & $\begin{array}{l}2804 \\
3.50\end{array}$ & & \\
\hline \multirow{2}{*}{$\begin{array}{l}\text { Total of } \\
\text { Aspects }\end{array}$} & Male & 123 & $\begin{array}{l}227 . \\
07\end{array}$ & $\begin{array}{l}2793 \\
0.00\end{array}$ & \multirow{2}{*}{$\begin{array}{l}5157.0 \\
0\end{array}$} & \multirow{2}{*}{$\begin{array}{l}0.00 \\
0\end{array}$} \\
\hline & Female & 207 & $\begin{array}{l}128 . \\
91\end{array}$ & $\begin{array}{l}2668 \\
5.00\end{array}$ & & \\
\hline
\end{tabular}

As appeared in table (7), there were significant differences between faculty staff members' responses on the availability of E-learning competencies, related to gender variable (Male, Female), in favour of male gender, therefore the Null hypothesis is rejected. The researchers attribute this to the fact that the Elearning competencies are related to the gender variable, and that the male gender have E- learning competencies more than females, these results due to the fact that, the males have more free time than females, which give them an opportunity to enrol in e-learning training courses. 


\section{E. The Fourth Hypothesis}

There are no significant differences at the level of significance (0.05) between faculty staff members' responses on the availability of E-learning competencies, related to experience variable.

H0: $\mu 1=\mu 2$

HA: $\mu 1 \neq \mu 2$

This hypothesis aimed to indicate that, whether the experience variable has an effect on faculty staff members' responses on the availability of E-learning competencies. To test this hypothesis, the T-test was used for the difference between two independent sample averages and the results were shown in table (8).

\section{TABLE 8}

MEANS AND STD. DEVIATION AND T-TEST VALUES OF STUDY PARTICIPANTS

\begin{tabular}{|c|c|c|c|c|c|c|c|c|c|c|}
\hline \multirow[t]{2}{*}{ Aspects } & \multirow[t]{2}{*}{$\begin{array}{l}\text { Exper } \\
\text { ience }\end{array}$} & \multirow[t]{2}{*}{$\mathbf{N}$} & \multirow[t]{2}{*}{$\begin{array}{l}\text { Me } \\
\text { an }\end{array}$} & \multirow{2}{*}{$\begin{array}{l}\text { Std } \\
\text { De } \\
\text { v. }\end{array}$} & \multirow[t]{2}{*}{$\mathbf{t}$} & \multirow[t]{2}{*}{ df } & \multirow{2}{*}{$\begin{array}{l}\text { Sig. } \\
(2 \\
\text { tail } \\
\text { ed })\end{array}$} & \multicolumn{2}{|c|}{$\begin{array}{l}95 \% \\
\text { confidenc } \\
\text { e }\end{array}$} & \multirow[t]{2}{*}{$\begin{array}{l}\text { Sig } \\
\text {. }\end{array}$} \\
\hline & & & & & & & & $\mathbf{L}$ & $\mathbf{U}$ & \\
\hline \multirow{2}{*}{$\begin{array}{l}\text { 1-The } \\
\text { compet } \\
\text { encies } \\
\text { of using } \\
\text { comput } \\
\text { er and } \\
\text { its } \\
\text { accesso } \\
\text { ries }\end{array}$} & $\begin{array}{l}\text { Less } \\
\text { than } 5 \\
\text { years }\end{array}$ & $\begin{array}{l}1 \\
5\end{array}$ & $\begin{array}{l}68 . \\
20\end{array}$ & $\begin{array}{l}9.3 \\
8\end{array}$ & \multirow[b]{2}{*}{$\begin{array}{l}- \\
1.1 \\
56\end{array}$} & \multirow[b]{2}{*}{$\begin{array}{l}3 \\
2 \\
8\end{array}$} & \multirow[b]{2}{*}{$\begin{array}{l}0.2 \\
49\end{array}$} & \multirow{2}{*}{$\begin{array}{l}- \\
6 . \\
9 \\
2 \\
3\end{array}$} & \multirow[b]{2}{*}{$\begin{array}{l}1.7 \\
99\end{array}$} & \multirow[b]{2}{*}{$\begin{array}{l}0.3 \\
74\end{array}$} \\
\hline & $\begin{array}{l}5 \\
\text { years } \\
\text { and } \\
\text { more }\end{array}$ & $\begin{array}{l}3 \\
1 \\
5\end{array}$ & $\begin{array}{l}70 . \\
76\end{array}$ & $\begin{array}{l}8.3 \\
4\end{array}$ & & & & & & \\
\hline \multirow{2}{*}{$\begin{array}{l}\text { 2- The } \\
\text { compet } \\
\text { encies } \\
\text { of using } \\
\text { network } \\
\text { s and } \\
\text { the } \\
\text { Internet }\end{array}$} & $\begin{array}{l}\text { Less } \\
\text { than } 5 \\
\text { years }\end{array}$ & $\begin{array}{l}1 \\
5\end{array}$ & $\begin{array}{l}60 . \\
00\end{array}$ & $\begin{array}{l}6.6 \\
4\end{array}$ & \multirow{2}{*}{$\begin{array}{l}- \\
1.0 \\
26\end{array}$} & \multirow{2}{*}{$\begin{array}{l}3 \\
2 \\
8\end{array}$} & \multirow[b]{2}{*}{$\begin{array}{l}0.3 \\
06\end{array}$} & \multirow{2}{*}{$\begin{array}{l}- \\
5 . \\
5 \\
8 \\
4\end{array}$} & \multirow[b]{2}{*}{$\begin{array}{l}1.7 \\
56\end{array}$} & \multirow[b]{2}{*}{$\begin{array}{l}0.7 \\
36\end{array}$} \\
\hline & $\begin{array}{l}5 \\
\text { years } \\
\text { and } \\
\text { more }\end{array}$ & $\begin{array}{l}3 \\
1 \\
5\end{array}$ & $\begin{array}{l}61 . \\
91\end{array}$ & $\begin{array}{l}7.0 \\
7\end{array}$ & & & & & & \\
\hline \multirow{2}{*}{$\begin{array}{l}\text { 3- The } \\
\text { compet } \\
\text { encies } \\
\text { of E- } \\
\text { learning } \\
\text { culture }\end{array}$} & $\begin{array}{l}\text { Less } \\
\text { than } 5 \\
\text { years }\end{array}$ & $\begin{array}{l}1 \\
5\end{array}$ & $\begin{array}{l}63 . \\
40\end{array}$ & $\begin{array}{l}12 . \\
04\end{array}$ & \multirow{2}{*}{$\begin{array}{l}- \\
1.3 \\
42\end{array}$} & \multirow{2}{*}{$\begin{array}{l}3 \\
2 \\
8\end{array}$} & \multirow[b]{2}{*}{$\begin{array}{l}0.1 \\
81\end{array}$} & \multirow{2}{*}{$\begin{array}{l}- \\
8 . \\
6 \\
4 \\
2\end{array}$} & \multirow[b]{2}{*}{$\begin{array}{l}1.6 \\
32\end{array}$} & \multirow[b]{2}{*}{$\begin{array}{l}0.1 \\
54\end{array}$} \\
\hline & $\begin{array}{l}5 \\
\text { years } \\
\text { and } \\
\text { more }\end{array}$ & $\begin{array}{l}3 \\
1 \\
5\end{array}$ & $\begin{array}{l}66 . \\
90\end{array}$ & $\begin{array}{l}9.7 \\
7\end{array}$ & & & & & & \\
\hline \multirow{2}{*}{$\begin{array}{l}\text { 4- The } \\
\text { compet } \\
\text { encies } \\
\text { of } \\
\text { designi } \\
\text { ng and } \\
\text { managi } \\
\text { ng E- } \\
\text { learning }\end{array}$} & $\begin{array}{l}\text { Less } \\
\text { than } 5 \\
\text { years }\end{array}$ & $\begin{array}{l}1 \\
5\end{array}$ & $\begin{array}{l}57 . \\
60\end{array}$ & $\begin{array}{l}15 . \\
31\end{array}$ & \multirow[b]{2}{*}{$\begin{array}{l}- \\
3.1 \\
09\end{array}$} & \multirow[b]{2}{*}{$\begin{array}{l}3 \\
2 \\
8\end{array}$} & \multirow[b]{2}{*}{$\begin{array}{l}0.0 \\
02\end{array}$} & \multirow{2}{*}{$\begin{array}{l}- \\
1 \\
5 . \\
1 \\
9 \\
1\end{array}$} & & \multirow[b]{2}{*}{$\begin{array}{l}0.0 \\
14 \\
*\end{array}$} \\
\hline & $\begin{array}{l}5 \\
\text { years } \\
\text { and } \\
\text { more }\end{array}$ & $\begin{array}{l}3 \\
1 \\
5\end{array}$ & $\begin{array}{l}66 . \\
90\end{array}$ & $\begin{array}{l}11 . \\
11\end{array}$ & & & & & $\begin{array}{l}- \\
3.4 \\
17\end{array}$ & \\
\hline
\end{tabular}

*Significant differences at the level of significance (0.05) and less
Table (8) showed that the mean value of the experience from 5 years and more (66.90), whereas, experience less than 5 years (57.60), for the fourth aspect (the faculty staff members competencies of designing and managing e-learning. The calculated $t$ value is (3.109) which is bigger than the statistical t table value (1.960), df (328). As Cal $t>$ Tab $t$ and Sig. (2-tailed) (0.002) is less than 0.025. Sig (0.014) > Sig (0.05). This indicated that there are significant differences at the level of sig. (0.05) between experience from 5 years and more and experience less than 5 years in favour of the experience from 5 years and more. It is noticed from Table (8) there were no significant differences, in the other aspects due to the differences in experience variable.

The researcher attributes the result showed in table (8) to the fact that the e-learning competencies (using computers, using internet, and e-leaning culture) are not related to the experience in teaching, and that because most of the faculty staff members at Jazan University use computers in their daily lectures, and they use the Internet in their lectures and in taking attendance for their students through their webpage at the university's academic system. But for e-learning competencies of designing and management of elearning the result related to the experience variable, that may be due to the scarcity of training on this elearning competency for all faculty staff members

\section{F. The Fifth Hypothesis}

There are no significant differences at the level of significance $(0.05)$ between faculty staff members' responses on the availability of E-learning competencies, related to qualification variable.

$$
\begin{aligned}
& \text { H0: } \mu 1=\mu 2 \\
& \text { HA: } \mu 1 \neq \mu 2
\end{aligned}
$$

This hypothesis aimed to indicate that, whether the qualification variable has an effect on faculty staff members' responses on the availability of E-learning competencies. To test this hypothesis, the T-test was used for the difference between two independent 
sample averages and the results were shown in table (9).

\section{TABLE 9}

MEANS AND STD. DEVIATION AND T-TEST OF THE STUDY PARTICIPANTS

\begin{tabular}{|c|c|c|c|c|c|c|c|c|c|c|}
\hline \multirow[t]{2}{*}{ Aspects } & \multirow[t]{2}{*}{$\begin{array}{l}\text { Qualific } \\
\text { ation }\end{array}$} & \multirow[t]{2}{*}{$\mathbf{N}$} & \multirow[t]{2}{*}{$\begin{array}{l}\text { Me } \\
\text { an }\end{array}$} & \multirow{2}{*}{$\begin{array}{l}\text { Std } \\
\text { De } \\
\text { v. }\end{array}$} & \multirow[t]{2}{*}{$\mathbf{t}$} & \multirow[t]{2}{*}{ df } & \multirow{2}{*}{$\begin{array}{l}\text { Sig. } \\
\text { g(2 } \\
\text { tail } \\
\text { ed })\end{array}$} & \multicolumn{2}{|c|}{$\begin{array}{l}95 \% \\
\text { confidenc } \\
\text { e }\end{array}$} & \multirow[t]{2}{*}{$\begin{array}{l}\text { Sig } \\
\text {. }\end{array}$} \\
\hline & & & & & & & & $\mathbf{L}$ & $\mathbf{U}$ & \\
\hline \multirow{2}{*}{$\begin{array}{l}\text { 1-The } \\
\text { compete } \\
\text { ncies of } \\
\text { using } \\
\text { compute } \\
\mathrm{r} \text { and its } \\
\text { accessor } \\
\text { ies }\end{array}$} & $\begin{array}{l}\text { Assistant } \\
\text { Professo } \\
\mathrm{r} \quad \text { and } \\
\text { above }\end{array}$ & $\begin{array}{l}1 \\
9 \\
5\end{array}$ & $\begin{array}{l}70 . \\
44\end{array}$ & $\begin{array}{l}7.9 \\
2\end{array}$ & \multirow{2}{*}{$\begin{array}{l}- \\
0.5 \\
18\end{array}$} & \multirow{2}{*}{$\begin{array}{l}3 \\
2 \\
8\end{array}$} & \multirow{2}{*}{$\begin{array}{l}0.60 \\
5\end{array}$} & \multirow{2}{*}{$\begin{array}{l}- \\
2.3 \\
37\end{array}$} & \multirow{2}{*}{$\begin{array}{l}1.3 \\
63\end{array}$} & \multirow{2}{*}{$\begin{array}{l}0.5 \\
04\end{array}$} \\
\hline & $\begin{array}{l}\text { Lecturer } \\
\text { and less }\end{array}$ & $\begin{array}{l}1 \\
3 \\
5\end{array}$ & $\begin{array}{l}70 . \\
93\end{array}$ & $\begin{array}{l}9.0 \\
5\end{array}$ & & & & & & \\
\hline \multirow{2}{*}{$\begin{array}{l}\text { 2- The } \\
\text { compete } \\
\text { ncies of } \\
\text { using } \\
\text { network } \\
\text { s and the } \\
\text { Internet }\end{array}$} & $\begin{array}{l}\text { Assistant } \\
\text { Professo } \\
\mathrm{r} \text { and } \\
\text { above }\end{array}$ & $\begin{array}{l}1 \\
9 \\
5\end{array}$ & $\begin{array}{l}61 . \\
75\end{array}$ & $\begin{array}{l}7.0 \\
2\end{array}$ & \multirow{2}{*}{$\begin{array}{l}- \\
0.2 \\
27\end{array}$} & \multirow{2}{*}{$\begin{array}{l}3 \\
2 \\
8\end{array}$} & \multirow{2}{*}{$\begin{array}{l}0.82 \\
1\end{array}$} & \multirow{2}{*}{$\begin{array}{l}- \\
1.7 \\
36\end{array}$} & \multirow{2}{*}{$\begin{array}{l}1.3 \\
77\end{array}$} & \multirow{2}{*}{$\begin{array}{l}0.9 \\
77\end{array}$} \\
\hline & $\begin{array}{l}\text { Lecturer } \\
\text { and less }\end{array}$ & $\begin{array}{l}1 \\
3 \\
5\end{array}$ & $\begin{array}{l}61 . \\
93\end{array}$ & $\begin{array}{l}7.1 \\
3\end{array}$ & & & & & & \\
\hline \multirow{2}{*}{$\begin{array}{l}\text { 3- The } \\
\text { compete } \\
\text { ncies of } \\
\text { E- } \\
\text { learning } \\
\text { culture }\end{array}$} & $\begin{array}{l}\text { Assistant } \\
\text { Professo } \\
\mathrm{r} \quad \text { and } \\
\text { above }\end{array}$ & $\begin{array}{l}1 \\
9 \\
5\end{array}$ & $\begin{array}{l}67 . \\
58\end{array}$ & $\begin{array}{l}10 . \\
00\end{array}$ & \multirow{2}{*}{$\begin{array}{l}1.8 \\
59\end{array}$} & \multirow{2}{*}{$\begin{array}{l}3 \\
2 \\
8\end{array}$} & \multirow{2}{*}{$\begin{array}{l}0.06 \\
4\end{array}$} & \multirow{2}{*}{$\begin{array}{l}- \\
0.1 \\
19\end{array}$} & \multirow{2}{*}{$\begin{array}{l}4.2 \\
22\end{array}$} & \multirow{2}{*}{$\begin{array}{l}0.9 \\
94\end{array}$} \\
\hline & $\begin{array}{l}\text { Lecturer } \\
\text { and less }\end{array}$ & $\begin{array}{l}1 \\
3 \\
5\end{array}$ & $\begin{array}{l}65 . \\
53\end{array}$ & $\begin{array}{l}9.6 \\
3\end{array}$ & & & & & & \\
\hline \multirow{2}{*}{$\begin{array}{l}4-\quad \text { The } \\
\text { compete } \\
\text { ncies of } \\
\text { designin } \\
\mathrm{g} \text { and } \\
\text { managin }\end{array}$} & $\begin{array}{l}\text { Assistant } \\
\text { Professo } \\
\mathrm{r} \text { and } \\
\text { above }\end{array}$ & $\begin{array}{l}1 \\
9 \\
5\end{array}$ & $\begin{array}{l}67 . \\
40\end{array}$ & $\begin{array}{l}11 . \\
54\end{array}$ & \multirow{2}{*}{$\begin{array}{l}1.7 \\
53\end{array}$} & \multirow{2}{*}{$\begin{array}{l}3 \\
2 \\
8\end{array}$} & \multirow{2}{*}{$\begin{array}{l}0.08 \\
1\end{array}$} & \multirow{2}{*}{$\begin{array}{l}- \\
0.2 \\
74\end{array}$} & \multirow{2}{*}{$\begin{array}{l}4.7 \\
63\end{array}$} & \multirow{2}{*}{$\begin{array}{l}0.8 \\
48\end{array}$} \\
\hline & $\begin{array}{l}\text { Lecturer } \\
\text { and less }\end{array}$ & $\begin{array}{l}1 \\
3 \\
5\end{array}$ & $\begin{array}{l}65 . \\
15\end{array}$ & $\begin{array}{l}11 . \\
28\end{array}$ & & & & & & \\
\hline
\end{tabular}

No significant differences at the level of significance (0.05) and less

Table (9) showed that there are no statistically significant differences at the level of significance (0.05) and less in the E-learning competencies among the faculty staff members, due to the difference in the qualification variable (Assistant Professor and above, Lecturer and less). The researcher attributes this result to the fact that the e-learning competencies are not related to the qualification, and that all faculty staff members with their different qualifications carry out the same teaching tasks in the university, under the same circumstances, and may be due to the scarcity of training on any of the e-learning competencies for all members of the university's faculty regardless of their teaching qualification.

\section{G. The Sixth Hypothesis}

There are no significant differences at the level of significance (0.05) between faculty staff members' responses on the availability of E-learning competencies, related to training course variable.

$$
\text { H0: } \mu 1=\mu 2=\mu 3
$$

HA: $\mu 1 \neq \mu 2 \neq \mu 3$

This hypothesis aimed to indicate that, whether the training course variable has an impact on the availability of E-learning competencies. To test this hypothesis, the One ANOVA Test was used. Table (10) showed the means and standard deviation values of the study participants.

TABLE 10

MEANS AND STD. DEVIATION VALUES OF STUDY PARTICIPANTS

\begin{tabular}{|c|c|c|c|c|c|c|}
\hline \multirow{2}{*}{ Aspects } & \multirow[t]{2}{*}{ Variable } & \multirow{2}{*}{$\mathbf{N}$} & \multirow{2}{*}{ Mean } & \multirow{2}{*}{$\begin{array}{l}\text { Std. } \\
\text { Dev. }\end{array}$} & \multicolumn{2}{|c|}{ 95\% Confidence } \\
\hline & & & & & $\mathbf{L}$ & $\mathbf{U}$ \\
\hline \multirow{3}{*}{$\begin{array}{l}\text { 1-The } \\
\text { competen } \\
\text { cies of } \\
\text { using } \\
\text { computer } \\
\text { and its } \\
\text { accessori } \\
\text { es }\end{array}$} & $\begin{array}{l}\text { None } \\
\text { training } \\
\text { course }\end{array}$ & 42 & 74.71 & 8.90 & $\begin{array}{l}71.9 \\
37 \\
\end{array}$ & 77.490 \\
\hline & $\begin{array}{l}\text { From One to } \\
\text { Two courses }\end{array}$ & 129 & 67.32 & 8.23 & $\begin{array}{l}65.8 \\
91\end{array}$ & 68.659 \\
\hline & $\begin{array}{l}\text { Three } \\
\text { courses and } \\
\text { above }\end{array}$ & 159 & 72.26 & 7.42 & $\begin{array}{l}71.1 \\
01\end{array}$ & 73.427 \\
\hline \multirow{3}{*}{$\begin{array}{l}2-\text { The } \\
\text { competen } \\
\text { cies of } \\
\text { using } \\
\text { networks } \\
\text { and the } \\
\text { Internet }\end{array}$} & $\begin{array}{l}\text { None } \\
\text { training } \\
\text { course }\end{array}$ & 42 & 65.78 & 6.29 & $\begin{array}{l}63.8 \\
22\end{array}$ & 67.748 \\
\hline & $\begin{array}{l}\text { From One to } \\
\text { Two courses }\end{array}$ & 129 & 58.72 & 7.38 & $\begin{array}{l}57.4 \\
35\end{array}$ & 60.006 \\
\hline & $\begin{array}{l}\text { Three } \\
\text { courses and } \\
\text { above }\end{array}$ & 159 & 63.30 & 5.92 & $\begin{array}{l}62.3 \\
73\end{array}$ & 64.230 \\
\hline \multirow{3}{*}{$\begin{array}{l}3-\quad \text { The } \\
\text { competen } \\
\text { cies of E- } \\
\text { learning } \\
\text { culture }\end{array}$} & $\begin{array}{l}\text { None } \\
\text { training } \\
\text { course }\end{array}$ & 42 & 72.35 & 7.42 & $\begin{array}{l}70.0 \\
43\end{array}$ & 74.670 \\
\hline & $\begin{array}{l}\text { From One to } \\
\text { Two courses }\end{array}$ & 129 & 62.81 & 8.95 & $\begin{array}{l}61.2 \\
54\end{array}$ & 64.373 \\
\hline & $\begin{array}{l}\text { Three } \\
\text { courses and } \\
\text { above }\end{array}$ & 159 & 68.45 & 10.03 & $\begin{array}{l}66.8 \\
81\end{array}$ & 70.024 \\
\hline \multirow{2}{*}{$\begin{array}{l}\text { 4- The } \\
\text { competen } \\
\text { cies of } \\
\text { designing } \\
\text { and } \\
\text { managin }\end{array}$} & $\begin{array}{l}\text { None } \\
\text { training } \\
\text { course }\end{array}$ & 42 & 74.50 & 8.49 & $\begin{array}{l}71.8 \\
53 \\
\end{array}$ & 77.146 \\
\hline & $\begin{array}{l}\text { From One to } \\
\text { Two courses }\end{array}$ & 129 & 62.27 & 10.77 & $\begin{array}{l}60.4 \\
02\end{array}$ & 60.155 \\
\hline $\begin{array}{l}\text { and } \\
\text { managin } \\
\text { g E- } \\
\text { learning }\end{array}$ & $\begin{array}{l}\text { Three } \\
\text { courses and } \\
\text { above }\end{array}$ & 159 & 67.77 & 11.31 & $\begin{array}{l}66.0 \\
00\end{array}$ & 69.546 \\
\hline
\end{tabular}


Table (10) showed the mean \& std. deviation values of study participants' responses on the availability of Elearning competencies, related to training course variable. The mean value of participants who have not attended any course (74.71, 74.50, 72.35, \& 65.78) respectively, whereas the mean value of the participants who have attended three courses and above $(72.26,68.45,67.77, \& 63.30)$ respectively, and the mean value of participants who have attend from $1-2$ courses $(67.32,62.81,62.27, \& 58.72)$ respectively, so, as showed in table (10), $\mu 1 \neq \mu 2 \neq \mu 3$. To verify this result, one-way ANOVA test was used, as appeared in Table (11).

\section{TABLE 11}

ONE-WAY ANOVA TEST TO FOND OUT DIFFERENCES BETWEEN STUDY PARTICIPANTS ACCORDING TO CLASSROOM VARIABLE

\begin{tabular}{|c|c|c|c|c|c|c|}
\hline Aspects & $\begin{array}{l}\text { Sourc } \\
\text { es of } \\
\text { contr } \\
\text { ast }\end{array}$ & $\begin{array}{l}\text { Sum of } \\
\text { squares }\end{array}$ & df & $\begin{array}{l}\text { Mean } \\
\text { square } \\
\text { s }\end{array}$ & $\mathbf{F}$ & Sig. \\
\hline \multirow{3}{*}{$\begin{array}{l}\text { 1-The } \\
\text { competen } \\
\text { cies of } \\
\text { using } \\
\text { computer } \\
\text { and its } \\
\text { accessorie } \\
\text { s }\end{array}$} & $\begin{array}{l}\text { Betwe } \\
\text { en } \\
\text { groups }\end{array}$ & $\begin{array}{l}2533.71 \\
6\end{array}$ & 2 & $\begin{array}{l}1266.8 \\
58\end{array}$ & $\begin{array}{l}20.0 \\
69\end{array}$ & $\begin{array}{l}0.00 \\
0\end{array}$ \\
\hline & $\begin{array}{l}\text { Withi } \\
\mathrm{n} \\
\text { groups }\end{array}$ & $\begin{array}{l}20641.8 \\
03\end{array}$ & $\begin{array}{l}32 \\
7\end{array}$ & 63.125 & & \\
\hline & Total & $\begin{array}{l}23175.5 \\
18\end{array}$ & $\begin{array}{l}32 \\
9 \\
\end{array}$ & & & \\
\hline \multirow{3}{*}{$\begin{array}{l}\text { 2- The } \\
\text { competen } \\
\text { cies of } \\
\text { using } \\
\text { networks } \\
\text { and the } \\
\text { Internet }\end{array}$} & $\begin{array}{l}\text { Betwe } \\
\text { en } \\
\text { groups }\end{array}$ & $\begin{array}{l}2248.62 \\
0\end{array}$ & 2 & $\begin{array}{l}1124.3 \\
10\end{array}$ & $\begin{array}{l}25.9 \\
74\end{array}$ & $\begin{array}{l}0.00 \\
0\end{array}$ \\
\hline & $\begin{array}{l}\text { Withi } \\
\mathrm{n} \\
\text { groups }\end{array}$ & $\begin{array}{l}14154.5 \\
34\end{array}$ & $\begin{array}{l}32 \\
7\end{array}$ & 43.286 & & \\
\hline & Total & $\begin{array}{l}16403.1 \\
55\end{array}$ & $\begin{array}{l}32 \\
9\end{array}$ & & & \\
\hline \multirow{3}{*}{$\begin{array}{l}\text { 3- The } \\
\text { competen } \\
\text { cies of E- } \\
\text { learning } \\
\text { culture }\end{array}$} & $\begin{array}{l}\text { Betwe } \\
\text { en } \\
\text { groups }\end{array}$ & $\begin{array}{l}3780.04 \\
4\end{array}$ & 2 & $\begin{array}{l}1890.0 \\
22\end{array}$ & $\begin{array}{l}21.7 \\
43\end{array}$ & $\begin{array}{l}0.00 \\
0\end{array}$ \\
\hline & $\begin{array}{l}\text { Withi } \\
\mathrm{n} \\
\text { groups }\end{array}$ & $\begin{array}{l}28424.5 \\
74\end{array}$ & $\begin{array}{l}32 \\
7\end{array}$ & 86.925 & & \\
\hline & Total & $\begin{array}{l}32204.6 \\
18\end{array}$ & $\begin{array}{l}32 \\
9\end{array}$ & & & \\
\hline \multirow{3}{*}{$\begin{array}{l}\text { 4- The } \\
\text { competen } \\
\text { cies of } \\
\text { designing } \\
\text { and } \\
\text { managing } \\
\text { E- } \\
\text { learning }\end{array}$} & $\begin{array}{l}\text { Betwe } \\
\text { en } \\
\text { groups }\end{array}$ & $\begin{array}{l}5244.08 \\
8\end{array}$ & 2 & $\begin{array}{l}2622.0 \\
44\end{array}$ & $\begin{array}{l}22.5 \\
34\end{array}$ & $\begin{array}{l}0.00 \\
0\end{array}$ \\
\hline & $\begin{array}{l}\text { Withi } \\
\mathrm{n} \\
\text { groups }\end{array}$ & $\begin{array}{l}38050.3 \\
03\end{array}$ & $\begin{array}{l}32 \\
7\end{array}$ & $\begin{array}{l}116.36 \\
2\end{array}$ & & \\
\hline & Total & $\begin{array}{l}43294.3 \\
91\end{array}$ & $\begin{array}{l}32 \\
9\end{array}$ & & & \\
\hline
\end{tabular}

Table (11) showed calculated (Cal) (F) value as an indication of differences between the study participants responses on the availability of Elearning competencies, related to training course variable. Cal (F) value was $(20.069,25.974,21.743$, \& 22.534), whereas $(\mathrm{F})$ value that derived from the statistical table (Tab) was (2.995). Since F Cal value $>$ F Tab value, and also level of significant adopted for this study (0.05)> (0.000). Thus, the null hypothesis (H0) (There were no significant differences between faculty staff members' responses on the availability of E-learning competencies, related to training course variable) was rejected. Once the null hypothesis was rejected, we have to determine which of the means is not equal, to verify this, comparison differences were used to compare every two mean values together, the hypotheses for this is as follows:

$\mathrm{H} 0: \mu \mathrm{i}=\mu \mathrm{j}$,

HA: $\mu \mathrm{i} \pm \mu \mathrm{j}, \mathrm{i}<\mathrm{j}=1,2,3$

TABLE 12

MULTIPLE COMPARISON TO COMPARE MEAN VALUES TO GETHER

\begin{tabular}{|c|c|c|c|c|c|c|c|}
\hline \multirow{2}{*}{ Aspects } & \multirow{2}{*}{$\begin{array}{l}\text { Train } \\
\text { ing } \\
\text { cours } \\
\text { es(i) }\end{array}$} & \multirow{2}{*}{$\begin{array}{c}\text { Train } \\
\text { ing } \\
\text { cours } \\
\text { es(j) }\end{array}$} & \multirow{2}{*}{$\begin{array}{c}\text { Mean } \\
\text { differ } \\
\text { ence } \\
\text { (i-j) }\end{array}$} & \multirow{2}{*}{$\begin{array}{c}\text { Std. } \\
\text { Erro } \\
\quad \mathbf{r}\end{array}$} & \multirow{2}{*}{ Sig. } & \multicolumn{2}{|c|}{$\begin{array}{c}95 \% \\
\text { Confidence }\end{array}$} \\
\hline & & & & & & $\mathbf{L}$ & $\mathbf{U}$ \\
\hline \multirow{5}{*}{$\begin{array}{l}\text { LSD 1- } \\
\text { The } \\
\text { compet } \\
\text { encies } \\
\text { of using } \\
\text { comput } \\
\text { er and } \\
\text { its } \\
\text { accesso } \\
\text { ries }\end{array}$} & \multirow{2}{*}{$\begin{array}{l}\text { None } \\
\text { traini } \\
\text { ng } \\
\text { cours } \\
\text { e }\end{array}$} & $\begin{array}{l}\text { From } \\
1-2 \\
\text { cours } \\
\text { es }\end{array}$ & $\begin{array}{l}7.388 \\
70^{*}\end{array}$ & $\begin{array}{l}1.41 \\
149\end{array}$ & $\begin{array}{l}0.0 \\
00\end{array}$ & $\begin{array}{l}4.61 \\
20\end{array}$ & $\begin{array}{l}10.1 \\
655\end{array}$ \\
\hline & & $\begin{array}{l}3 \\
\text { cours } \\
\text { es } \\
\text { and } \\
\text { abov } \\
\text { e }\end{array}$ & $\begin{array}{l}2.450 \\
13\end{array}$ & $\begin{array}{l}1.37 \\
840\end{array}$ & $\begin{array}{l}0.0 \\
76\end{array}$ & $\begin{array}{l}- \\
0.26 \\
14\end{array}$ & $\begin{array}{l}5.16 \\
18\end{array}$ \\
\hline & \multirow{2}{*}{$\begin{array}{l}\text { From } \\
1-2 \\
\text { cours } \\
\text { es }\end{array}$} & $\begin{array}{l}\text { None } \\
\text { traini } \\
\text { ng } \\
\text { cours } \\
\text { e }\end{array}$ & $\begin{array}{l}- \\
7.388 \\
70^{*}\end{array}$ & $\begin{array}{l}1.41 \\
149\end{array}$ & $\begin{array}{l}0.0 \\
00\end{array}$ & $\begin{array}{l}- \\
10.1 \\
655\end{array}$ & $\begin{array}{l}- \\
4.61 \\
20\end{array}$ \\
\hline & & $\begin{array}{l}3 \\
\text { cours } \\
\text { es } \\
\text { and } \\
\text { abov } \\
\text { e }\end{array}$ & $\begin{array}{l}- \\
4.938 \\
57^{*}\end{array}$ & $\begin{array}{l}0.94 \\
146\end{array}$ & $\begin{array}{l}0.0 \\
00\end{array}$ & $\begin{array}{l}- \\
6.79 \\
07\end{array}$ & $\begin{array}{l}- \\
3.08 \\
65\end{array}$ \\
\hline & $\begin{array}{l}\text { Thre } \\
\text { e }\end{array}$ & $\begin{array}{l}\text { None } \\
\text { traini }\end{array}$ & $\begin{array}{l}- \\
2.450\end{array}$ & $\begin{array}{l}1.37 \\
840\end{array}$ & $\begin{array}{l}0.0 \\
76\end{array}$ & $\begin{array}{l}- \\
5.16 \\
\end{array}$ & $\begin{array}{l}0.26 \\
15 \\
\end{array}$ \\
\hline
\end{tabular}




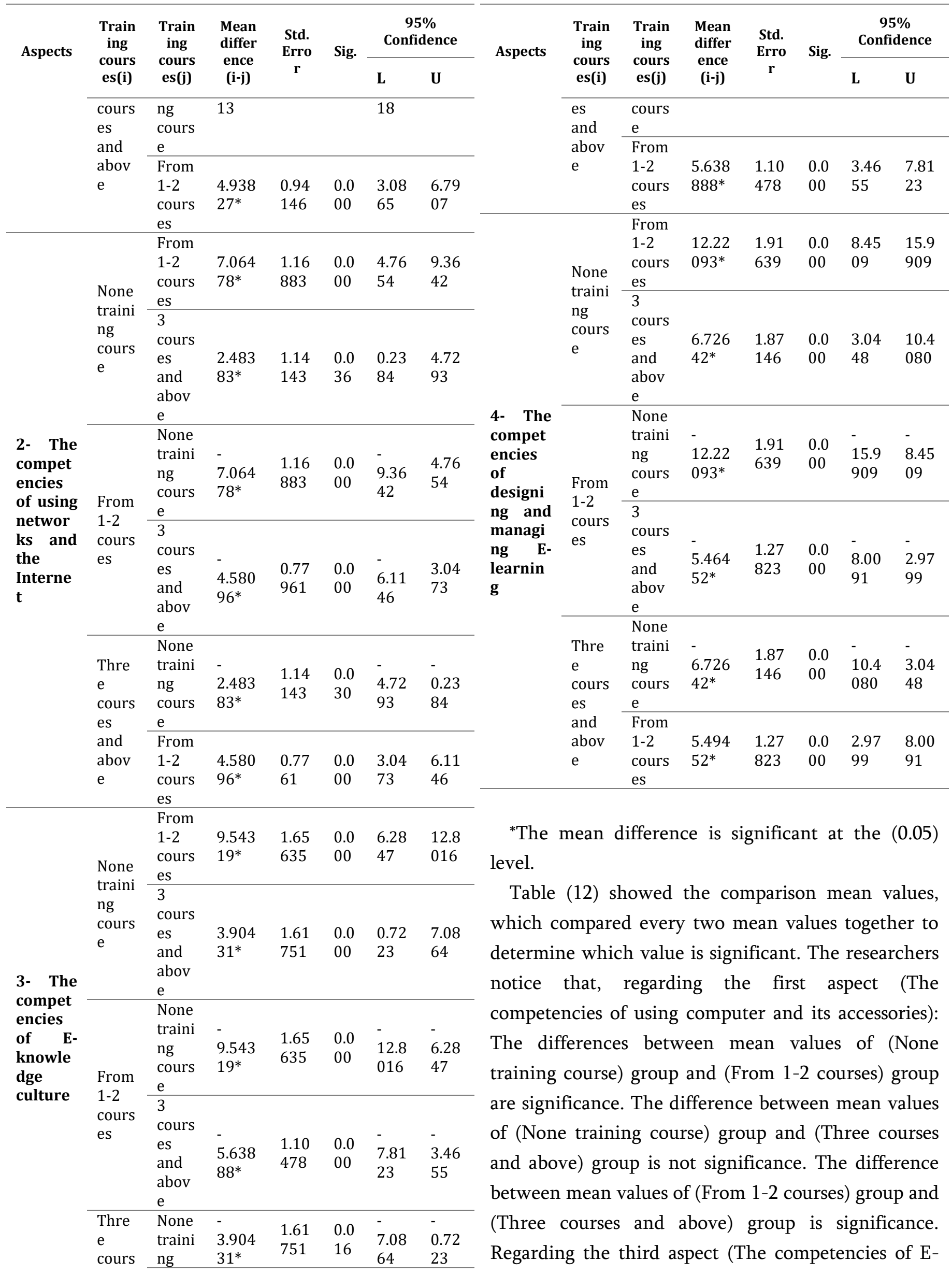


knowledge culture): The differences between mean values of (None training course) group and (From 1-2 courses) group are significance. The difference between mean values of (None training course) group and (Three courses and above) group is significance and the difference between mean values of (From 1-2 courses) group and (Three courses and above) group is significance. Regarding the fourth aspect (The competencies of designing and managing E- learning): The differences between mean values of (None training course) group and (From 1-2 courses) group are significance. The difference between mean values of (None training course) group and (Three courses and above) group is significance and the difference between mean values of (From 1-2 courses) group and (Three courses and above) group is significance. Regarding the second aspect (The competencies of using networks and the Internet): The differences between mean values of (None training course) group and (From 1-2 courses) group are significance. The difference between mean values of (None training course) group and (Three courses and above) group is significance and the difference between mean values of (From 1-2 courses) group and (Three courses and above) group is significance.

\section{IV.CONCLUSION}

The research concluded that:

1- Personal data of the faculty staff members were analysed. (63.6\%) of them were female; $(42.7 \%)$ of them were assistant professor; (58.2\%) of them were from Science colleges; $(52.7 \%)$ of them their experience ranged between 5-10 years; (47.3\%) of them were those who were attended more than three courses in e-learning.

2- According to study participants' response to the questionnaire aspects, the participants possess electronic learning competencies.

3- There were statistically significant differences in the aspects (competencies of e-learning culture) and (competencies of designing and managing e-learning) related to college variable, in favour of humanities colleges.

4- There were statistically significant differences between the faculty staff member responses on the availability of e-learning competencies, related to gender variable, in favour of male gender.

5- There were statistically significant differences in the aspect (competencies of designing and managing e-learning) related to experience variable, in favor of experience from 5 years and more.

6- There were statistically significant differences in the e-learning competencies, due to the difference in qualification variable.

7- There were statistically significant differences in the e-learning competencies, related to the training courses.

\section{RECOMENDATION}

Organizing training courses in the field of elearning for faculty members at Jazan University in the Kingdom of Saudi Arabia, especially in the field of designing and managing e-learning.

\section{SUGGESTION}

The researcher suggests conducting the following studies:

1- Conducting a similar study on other Saudi Arabian universities.

2- Conducting a study to find out the degree of availability of e-learning competencies among Jazan University students.

\section{REFERENCES}

[1]. Ahmed, Omer Au-El-Gasim (2014). The availability of e-learning competencies among the faculty members of the Colleges of Education in Sudanese universities, (Ph.D. Thesis), Al Azhary University, College of Education, Sudan. Available at: http://search.shamaa.org/FullRecord?ID=112694

[2]. Al-Hady, Muhammad (2005): E-learning via the Internet, the Egyptian Lebanese House, Al-Aqsa University. 
[3]. Al-Saif, Manal Suliman (2009). The Extent of ELearning Competencies Possession, Its Barriers and Development Methods from the point of view of the college of Education' staff members, (Master thesis), College of Education, King Saud University. Available

https://www.yumpu.com/en/document/view/429442 22/137283532343737247-

[4]. Al-Umary, Ali Marad Mousa (2009). Electronic learning competencies and their degree of availability among the high school teachers at AlMekhwah Educational Governorate, (Master Thesis), p3. Um-Al-Gora University, College of Education. Available at: http://www.manaraa.com/Research_topic/

[5]. Duffin, E. (2020). E-learning and digital educationstatistics and facts. Available at: https://www.statista.com/topics/3115/e-learningand-digital-education/

[6]. Gulbahar, yasemin \& Kalelioglu, Filiz (2015). Competencies for e-learning instructors: How to Qualify and Guarantee Sustainability, Journal of Contemporary Educational technology, 6 (2), pp. 140-143. Available at: https://www.researchgate.net/publication/27527426 9

[7]. Hassan, Khalida Mohamed Ali (2017). E-Learning Competencies and its Availability for private Secondary School Teachers, (Master Thesis), Sudan University of Science and Technology, College of Education. Available at: http://repository.sustech.edu/handle/123456789/188 08

[8]. Kinsara, Ihsan Muhammad (2005): The extent to which faculty staff members at Umm Al-Qura University possess the technological competencies and the extent of their practice of them and the difficulties they face, 1st edition, Educational and Psychological Research Series, Mecca, Umm AlQura University.

[9]. Kulab, Rami Mohammed (2011). The degree of elearning competencies of the computerized interactive learning (CIL) teachers at UNRWA schools in Gaza and its relationship to their attitudes, (Master Thesis) Al-Azhar University Gaza, Deanship of Higher Studies, College of
Education, Curricula and teaching methods, p 3 \&10. Available at: http://www.mobt3ath.com/uplode/book-9792.pdf

[10]. Merdas, Khalid Abdelaziz (2014). E-learning competencies among teachers of Islamic education teachers at higher school in some States of Kuwait, Journal of Educational and Psychological Studies, Zagazig University, (45) Part 2. Pp. 41-66. Available at:

http://search.shamaa.org/PDF/Articles/EGMktz/Mkt zNo85P2Y2014/mktz_2014-n85-p2_041-102.pdf

[11]. Reichert, S., \& Tauch, C. (2005). Trends IV: European Universities Implementing Bologna. In E. C. D. G. f. E. a. Culture (Ed.), EUA - European Quality Assurance.

[12]. Sallam, Marwan Hasan (2013). The availability of elearning competencies among the faculty members at the University of Ibb, Yemen, (Master Thesis), University of King Saud, College of Education. Available at: http://www.academia.edu/3626336/

[13]. Sayegh, Wafa Hasan (2017). The degree to which faculty members possess e-learning competencies and the extent of their practice thereof, (Ph.D. Thesis), Um-Al-Gora University, College of Education. Available at: http://www.search.mandumah.com/Record/611609

[14]. Sultan, Ahmad (2001)."The need to Go Beyond "Techno-centrism" in Educational Technology: Implementing the Electronic Classroom in the Arab World", 2nd International Conference on USE Education Reform, Dubai, UAE.

\section{Cite this article as :}

Mahasin Gadalla Mohamed, Kadia Mohammad Alfaifi, "The Degree of Availability of E-Learning Competencies : A Survey Study Among the Faculty Staff Members at Jazan University- Saudi Arabia", International Journal of Scientific Research in Science and Technology (IJSRST), Online ISSN : 2395-602X, Print ISSN : 2395-6011, Volume 8 Issue 2, pp. 489-509, March-April 2021. Available at doi : https://doi.org/10.32628/IJSRST218279 Journal URL : https://ijsrst.com/IJSRST218279 